Jpn. J. Oral Biol., $28: 12-18,1986$.

\title{
コラーゲンゲルマトリックスを用いたマウス 正常顎下腺上皮細胞の初代培養
}

\author{
米田俊之今 本 公 作田正義 \\ 大阪大学歯学部口腔外科第二講座
}

[受付 : 昭和60年10月25日]

\section{Primary culture of mouse submandibular gland epithelial cells Embedded in collagen gel matrix}

\author{
Toshiyuki Yoneda, Akira Imamoto and Masayoshi Sakuda \\ Second Department of Oral and Maxillofacial Surgery, Faculty of Dentistry, \\ Osaka University, 1-8 Yamadaoka, Suita, Osaka
}

〔Accepted publication: October 25, 1985]

Key words : Submandibular epithelial cells/primary culture / collagen gel matrix / growth / differentia-
tion

\begin{abstract}
Salivary epithelial cells were isolated by collagenase digestion of male mouse (C57BL/6N) submandibular gland. Isolated cells (MSG cells) were embedded in the collagen (Type I) gel matrix. MSG cells demonstrated three-dimensional outgrowth with duct-like structures extending into the matrix. Growth of the cells reached 30 -fold of that at plating after 3 weeks in culture, whereas fibroblasts did not grow in the matrix. In addition, MSG cells showed significant activity of amylase secretion into the culture medium even after 3 weeks in culture. Thus, MSG cells retained not only growth but differentiation when cultured in the collagen gel matrix. It is suggested that culture of MSG cells in the collagen gel matrix is a useful technique to study the effects of a variety of hormones and growth factors on the growth and differentiation of MSG cells.
\end{abstract}

\section{緒言}

唾液腺は, 口腔領域に属する臟器の中で最も代 謝活性が高く，さまざまの機能を有していること はよく知られている。中でも近年顎下腺（特にマ ウスの）が非常に強い生物学的活性を有する種々 のポリペプチドを産出していること，そしてその 産出が各種のホルモン，例えばアンドロゲン，甲 状腺ホルモン，あるいはステロイドホルモン等に よって強く影響を受けるということから，特に注 目されている ${ }^{1,2)}$ 。れらの点をより詳細にかつ系 統的に検索するための手段の一つとして顎下腺細 胞の培養は極めて有益であると考えられる。その ためこれまで色々な培養法が試みられてきた。し

吹田市山田丘 1-8（广 565）
かしながら，いずれの場合においても分離された 顎下腺細胞は増殖能が非常に弱く，培養期間が長 期にわたるにつれて細胞の活性及び分化機能が失 なわれ，さらには分離の際に混入したと思われる 線維芽細胞の過増殖が見られるようになり，唾液 腺上皮細胞としての機能を長期間保持さ せ続ける ことは困難であった ${ }^{3)}$ 。1980年に Yang らは正常 乳腺細胞をコラーゲンゲル内に包埋した状態で培 羕すると， 細胞はかなりの期間，分化機能を保持 しながら旺盛な増殖を示すことを報告した ${ }^{4}$ 。そし て彼等は同じ方法を用いて, マウス正常顎下腺上 皮細胞の培養を試みた結果，乳腺細胞の場合と同 様に，頡下腺細胞を三次元的に，時には管腔構造 を示しながら増殖をさせることに成功しだ”。ま た，この培養法のもう一つの大きな利点はコラー ゲンゲル内で は線維芽細胞は殆んど増殖し得ない 
ということである。そこで，著者等も彼等の方法 に準じてマウス正常䫛下腺上皮細胞の培養を試み た。

\section{実験方法}

1. マウス嚬下腺上皮細胞（MSG 細胞）の分 離。

生後6 8週齢の雄 C57 BL/6N マウスより周囲 の結合組織を可及的に除去した両側䇗下腺を採取 (湿重量 $1 \mathrm{~g}$ 前後) し, 細切後 $10 \mathrm{~m} l / \mathrm{g}$ 組織の割合 で0.1\%コラゲナーゼ（クラス II， Cooper Biomedical, Hank の平衡塩類溶液に溶解）中で, ゆ っくり靦判しながら室温にて12 時間消化した。 得られた細胞奬濁液を孔径 $200 \mu \mathrm{m}$ のナイロンメ ッシュを通過させることによりゴミを除去し，ょ く洗滌した後コラーゲンゲル内で培養をおこなっ $た^{5)}$ 。ある実験においては細胞眯濁液を $30 \mathrm{~m} l$ の 42 \% Percoll (Pharmacia, $12.6 \mathrm{~m} l$ Percoll, $1.4 \mathrm{~m} l$ 10倍量 Waymouth 培地, $16 \mathrm{~m} l$ Saline A) 中で 密度勾配遠心法をおこなうことにより上皮細胞を 分離しだ。

2. コラーゲンゲル内培養法。

方法は Richards ")らに準じておこなった。まず $4^{\circ} \mathrm{C}$ にて Cellmatrix I (新田ゼラチン), 5 倍濃 度のダルベコー変法 MEM 培地 (DMEM 日水製 薬）及ぴ再構成用緩衝液 $(10 \mathrm{~m} l \quad 0.05 \mathrm{~N} \mathrm{NaOH}$, $220 \mathrm{mg} \mathrm{NaHCO}_{3}, 477 \mathrm{mg}$ HEPES) を7:2:1の 割合で混合しコラーゲンゲルを調製した。 $0.25 \mathrm{~m} l$ のコラーゲンゲルをプラスチックシャーレ（Linbro, $16 \mathrm{~mm}$ ) 上に加え (Base Layer), $37^{\circ} \mathrm{C}, 10$ 分 間放置しゲル化させた。次に $1 \times 10^{5} / \mathrm{m} l$ の MSG 細胞を含んだコラーゲンゲル $0.5 \mathrm{~m} l$ を重層し (Top Layer) $37^{\circ} \mathrm{C} 10$ 分間放置し，ゲル化させた。 そして最後に $1 \mathrm{~m} l$ の DMEM 培地 $(4.5 \mathrm{~g} / l$ グ ルコース, $110 \mathrm{mg} / l$ ピルビン酸ナトリウム, 100 単 位 $/ \mathrm{m} l$ ペニシリン $\mathrm{G}, 100 \mu \mathrm{g} / \mathrm{m} l$ ストレプトマイシ ン, $20 \mathrm{mM}$ HEPES, $1.1 \mathrm{~g} \mathrm{NaHCO}_{3}$ 及び $10 \%$ 牛 胎児血清を含む) を添加した。培養液は 3 日毎に 交換した。

\section{3. 細胞数の算定。}

MSG 細胞を包埋したコラーゲンゲルを含んだ プラスチックシャーレ $(16 \mathrm{~mm})$ に $1 \mathrm{~m} l$ の0.1\%コ

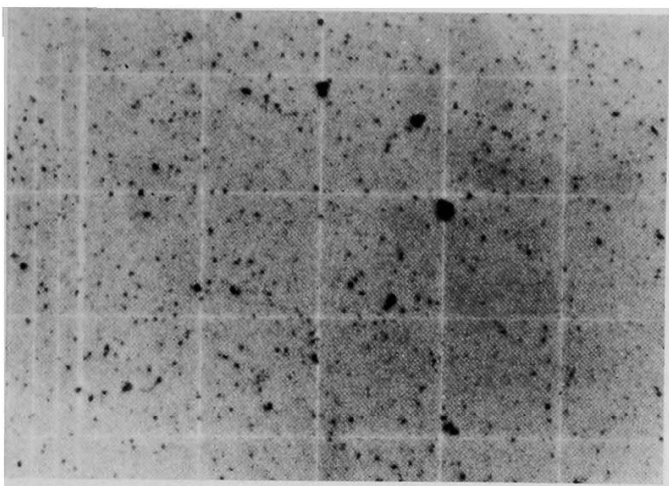

Fig. 1 Dispersed nuclei of MSG cells stained with $0.1 \%$ crystal violet in $0.1 \mathrm{M}$ citric acid. Number of stained nuclei was counted on a hemocytometer $(\times 100)$.

ラーゲナーゼ溶液を加え $37^{\circ} \mathrm{C} \quad 1$ 時間消化後, 得 られた細胞を $0.1 \%$ リスタル紫（和光純薬）と $0.1 \mathrm{M}$ クェン酸の混合液中 $(1: 1 \mathrm{~V} / \mathrm{V})$ で超音波 処理により破壊した。そして染色された核の数を 血球計算板上で算定した (Fig. 1) $)^{6)}$ 。

4. アミラーゼ活性の測定

細胞から培養液中に放出されたアミラーゼ活性 をCaraway 法 ${ }^{81}$ に準じて測定した。尚実際の測定 には和光純薬工業社製のアミラーゼテストワコー を用いた。

\section{5. 細胞の染色}

プラスチックシャーレの側壁内面に沿ってメス により MSG 細胞を含んだコラーゲンゲルを切り 取り, 10\%中性ホルマリン中で固定後, 通常の方 法で組織切片を作製し, ヘマトキシリン一エオシ ン染色を施した。

\section{結果}

\section{MSG 細胞の分離及び培養}

前述の方法を用いることにより，一匹のマウス の両側顎下腺より $2 \sim 3 \times 10^{6}$ 個の MSG 細胞を得 ることができた。また，我々の方法ではコラゲ ナーゼの作用時間が12時間と長いため Yang ら がおこなっているようにプロナーゼを用いなくて も，細胞を十分に分散させることが可能であっ た。Percoll の使用に関しては顎下腺の摘出の際 に注意深く周囲の結合組織を取り除けば，必ずし もPercoll による比重遠心をおこなわなくても線 

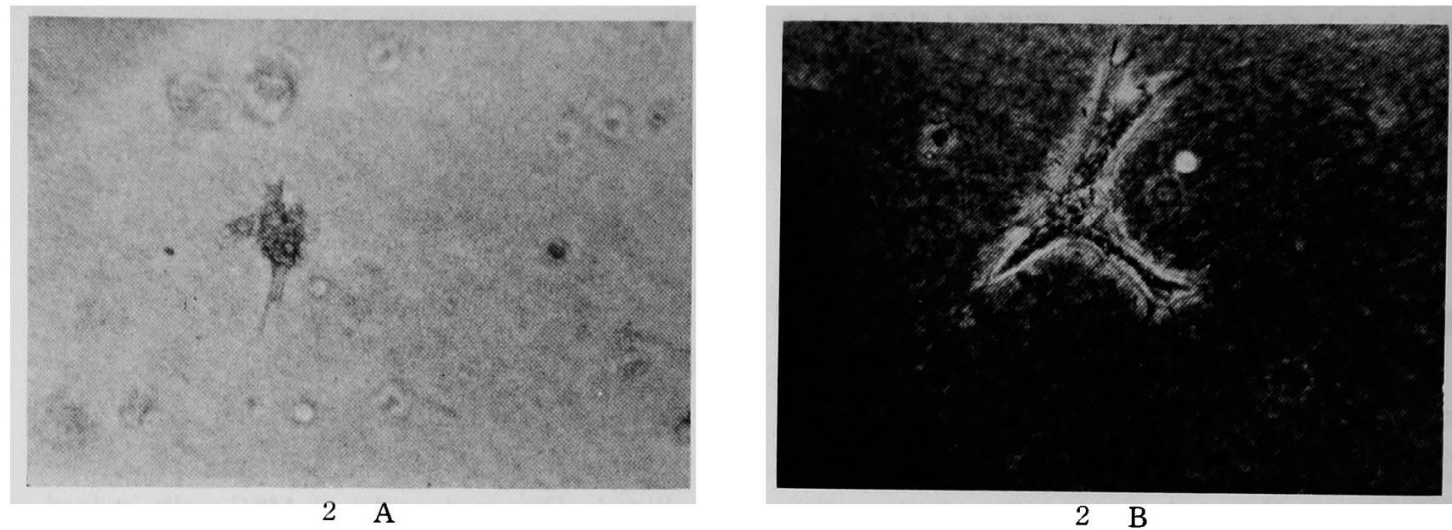

2 B
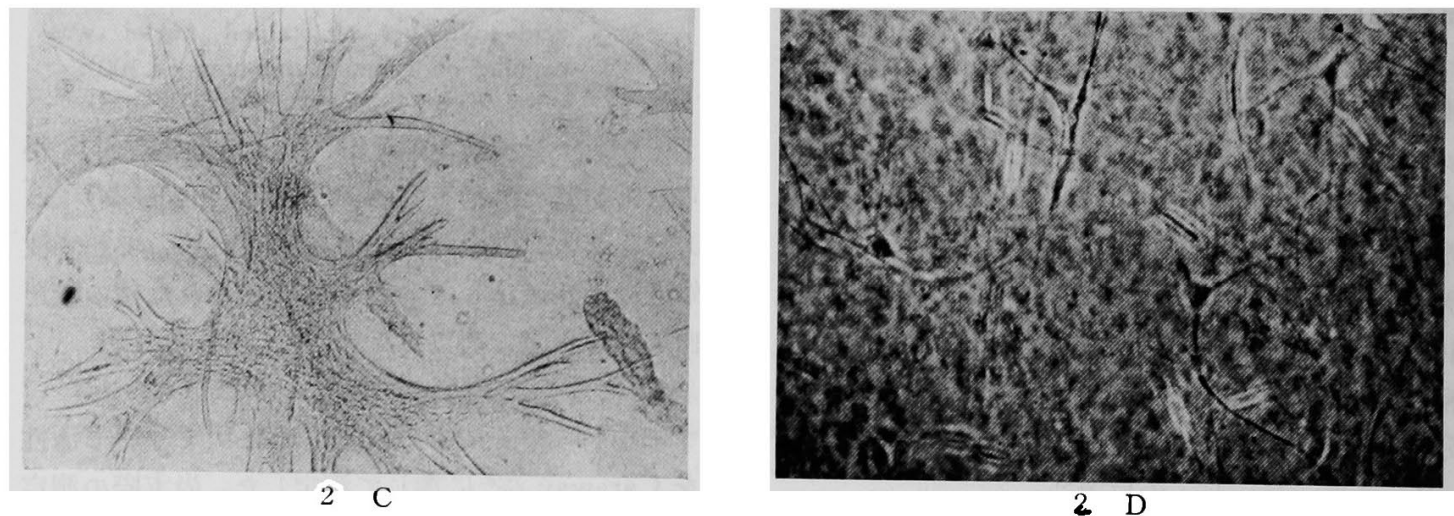

$2 \mathrm{D}$

Fig. 2 Phase contrast micrography of MSG cells cultured in the collagen gel matrix for A ; 3 days B ; 7 days $C$; 11 days $D$; Fibroblasts cultured in the gel for 11 days. Note that MSG cells proliferate by extending 'star-like' projections into the collagen gel, resulting in three-dimensional outgrowth. Fibroblasts in the gel showed characteristic morphology and were easily distingushable from MSG cells.

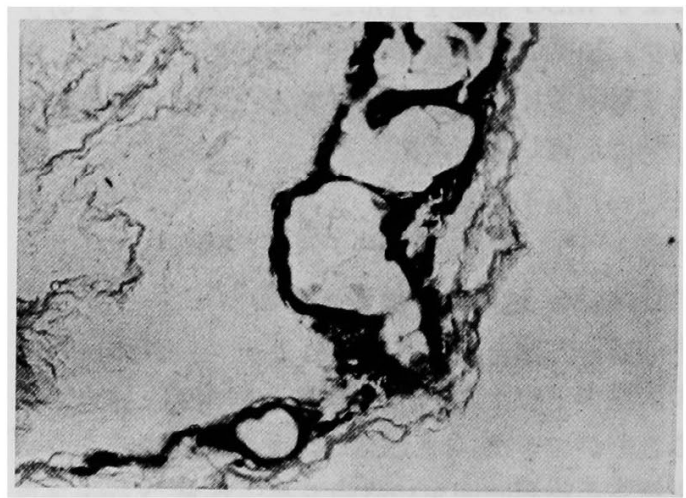

Fig. 3 Light micrograph of MSG cells embedded in the collagen gel for 30 days (H-E stain, $\times 100$ ).
維芽細胞の混入を防ぐことができた。Yang らも 同様の結果を報告している5゙。培養日数の経過 に伴うコラーゲンゲルマトリックス内における MSG 細胞の形態の変化を Fig. 2に示した。培養 3 日目頃までは MSG 細胞はコロニーを形成しな がら増殖したが (Fig. 2A)，それ以降は Fig. 2B 及びCに示すように，非常に特徴的な樹枝状形態 を呈しながら，そして三次元的に 旺盛に 増殖し た。この間, 線維芽細胞は Fig. 2D のように MSG 細胞とは明らかに異なる形態を示し，容易に区別 することができ，また培養日数の経過と共に死滅 した。Fig. 2C の状態の MSG 細胞を含んだコラ ーゲンゲルより組織切片を作製し，H-E 染色をお こなった結果, MSG 細胞が一部管状構造を形成 している像が認められた（Fig. 3)。 


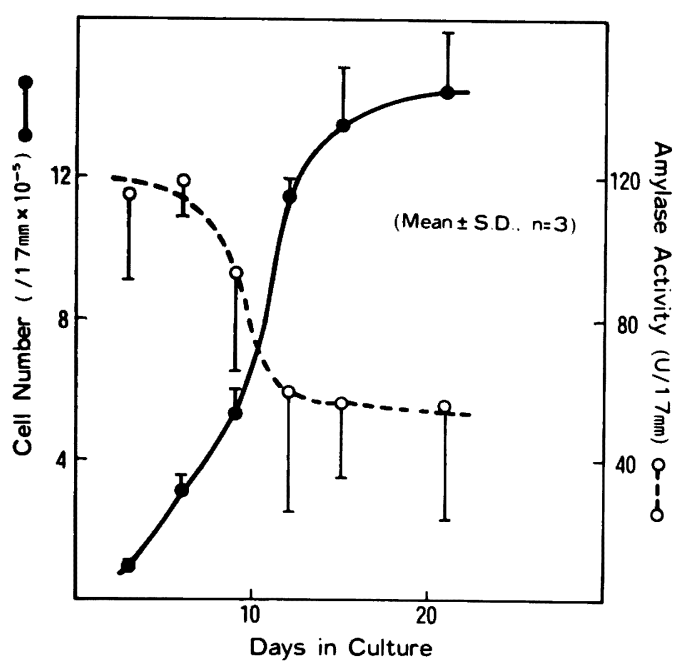

Fig. 4 Growth of and release of amylase by MSG cells cultured in the collagen gel.

\section{MSG 細胞の増殖。}

コラーゲンゲル内に $5 \times 10^{4}$ 個の MSG 細胞を播 種し, 細胞数の増加を検討したところ, 細胞の増 殖は培養20日前後で, ほぼ定常状態となりその数 は約 $1.5 \times 10^{6}$ 個と播種時の 30 倍に達した（Fig. 4)。

\section{MSG 細胞の機能。}

顎下腺細胞の機能の一つであるアミラーゼ活性 は培養3〜7日の MSG 細胞において最も高く，そ の後活性は徐々に低下したが，培養10日頃より大 きな変化はなく，20日頃まで有意の活性が認めら れた (Fig. 4)。

\section{考察}

1961年に Selye $ら^{91}$ がイソプロテノール投与に よりラットの唾液腺が著明に増殖することを報告 して以来, in vivo における DNA 合成の開始を 調節する因子を解析するための実験系として唾液 腺がよく利用されている ${ }^{10,11}$ 。 また顎下唾液腺が 産出するポリペプチドの一つである Epidermal Growth Factor(EGF)の合成がアンドロゲン依存 性であることから，ホルモンによる細胞の分化機 能の調節を検討するための実験系としても唾液腺 が in vivo における興味の対象となっている ${ }^{12,13)}$ 。 にもかかわらず in vivo において䪽下唾液腺細胞 の増殖及び分化をより詳細に検討するための最も
有効な手段である細胞培養は未だ確立されていな いのが現状である。顎下腺の器官培養を用いた実 験が報告されているが, 殆んどの場合, 組織は時 間の経過と共に変性に陥り，十分な実験をおこな うことができなかった ${ }^{14-16)}$ 。最近，井上らはシリ コン処理したレンズペーパー上で分化能を保持し た状態の耳下腺の器官培養をおこなうことに成功 し，各種ホルモンに対する応答性について検討し ている ${ }^{17)}$ 。この培養法は, 組織中の各種の細胞の 相互作用の結果あらわれる反応を見ることができ るという点で生理的状態をより反映していると考 えられるが，やはりその現象を解析する際に異種 の細胞つまり間葉系細胞と上皮系細胞とが混在し ていることによる複雑性が問題になると予想され る。過去において試みられた唾液腺細胞の培養 は, 分離された上皮性細胞が十分な増殖を示さな いという大きな欠点があり，さらに培羕が長期に 及ぶにつれて混入した間葉系細胞の旺盛な増殖の ために上皮性細胞は少数となり，もはや唾液腺細 胞として扱うことができなくなる場合が殆んどで

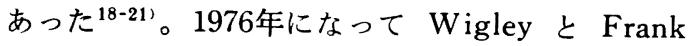
は, explant 培養法を用いてマウス顎下腺細胞の 培養をおこない，インシュリンと八イドロコーチ ゾンの存在下で細胞の DNA 合成が促進され, また少くとも 2 週間は, 顆粒管細胞の分泌機能の 指標の一つであるプロテアーゼ活性を保持させ ることができたと報告している221。Quissell と Redman はコラゲナーゼとヒアルロニダーゼを用 いてラットの䫟下腺細胞を分離し，この細胞が各 種の神経作働薬に対して強い反応性を示すことを 見い出した ${ }^{23)}$ 。その後これらの細胞を用いて，ア ミラーゼ分泌に対するカルシウムあるいはサイク リック AMP の役割について実験を行なってい $3^{24,25 \prime}$ 。しかし, 彼等が実験に用いた細胞は分離 直後のものであり，長期間培養した場合でもこの 細胞が各種ホルモンあるいは薬剤に対して応答す るか否かは不明である。さらに Oliver は同様に 酵素処理により分離した耳下腺腺房細胞をイソプ ロテレノール存在下で培養することにより，4 週 間以上分化機能を保持した状態で培養することが できたと報告している ${ }^{26)}$ 。しかしこれらの細胞は 増殖能が極めて弱いという点で問題がある。我が 
国においても Takemura と Ohshika が Quissell らと同様の方法を用いてラット耳下腺細胞を分離 しアミラーゼ分泌に対する各種薬剤の効果を検討 しているが，彼等の場合も分離直後の細胞を用い

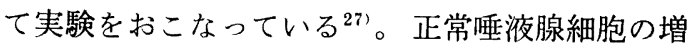
殖能が非常に低いという問題を腫瘍化した喠液腺 細胞を利用することにより克服しようとする試み

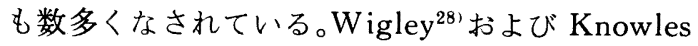
と Frank ${ }^{29)}$ は explant 培養により遊離増殖し てきた唾液腺上皮細胞を dimethylbenz（a） anthracene(DMBA) で処理することにより癌化した 細胞を確立した。そしてこれらの細胞を in vivo に戻すと腺癌を形成することを示した。しかしな がら, この癌化した唾液腺上皮細胞の機能に関し ては未だ明らかにされていない。機能を有するこ とが明らかにされている癌化した顎下腺細胞とし ては，Barka らがマウス顎下腺に DMBA を注射 することにより誘発させた腫瘍より分離, 確立し た細胞がある。この細胞は, 頡下腺顆粒管細胞の

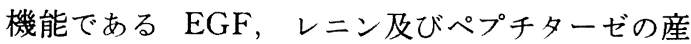
出能を有していることが証明されており ${ }^{301}$ ，今後 非常に有益な実験モデルになると考えられる。一 方我が国においても，Shirasuna らが，照射を受 けたヒト唾液腺より癌細胞の分離に成功してお $り^{311}$ ， 最近，この細胞が EGF と transforming growth factor- $\beta$ を産出していることが明らかに された ${ }^{32}$ 。ここように癌化した唾液腺細胞を利用 することにより正常唾液腺細胞では不可能であっ た増殖と分化について研究を進めることが可能で ある。しかし，この場合も腫瘍細胞において見ら れた現象をどの程度まで正常唾液腺細胞の機能と 関連ずけてよいのかという点で常に不安がつきま とう。

上皮性細胞の増殖および分化は間葉系細胞との 相互作用の上に成り立っていることはよく知られ
ている ${ }^{33)}$ 。特に間葉系細胞が合成分泌する細胞外 基質が重要な役割を果たしていると考えられてい る ${ }^{34)}$ 。唾液腺上皮細胞のみを分離して単層培養を おこなった場合には，支持組織としての基質が存 在しないために細胞は増殖および分化能を保持で きないと想像される。そこで，今回我々は Yang らの方法 ${ }^{1}$ に準じて，タイプI コラーゲンゲルを 支持組織として使用し，その中にマウス正常䪽下 腺細胞（MSG 細胞）を包埋した状態で培養をお こなった。その結果 MSG 細胞は特徴的な樹枝状 を呈しながら三次元的に旺盛に増殖した。培養 3 週後には細胞数が約30倍に達したのみならず線維 芽細胞の増殖は殆んど見られず，また多少活性は 低下するものの，有意のアミラーゼ分泌活性を示 した。さらにこの時期の細胞を組織学的に検索し た結果，管腔形成が認められた。つまりコラーゲ ンゲル内で培養することによりこれまでの細胞培 養に㧤いて問題となっていた点をほぼ解決でき, しかも in vivo に非常に近い状態で MSG 細胞の 増殖および分化を観察し得ることが明らかとなっ た。また Yang らは既に, この方法で培養された MSG 細胞は種々のホルモンあるいは成長因子に 対して応答性を示すこと源方として高い $\mathrm{EGF}$ 産生 能を有していることを報告している ${ }^{553)}$ 。さらに, オートラジオグラフィーによる DNA 合成の検 討 $^{36)}$ や電顕による MSG 細胞の観察も容易におこ なうことができる ${ }^{5,351}$ 。今後この培養法を用いる ことにより唾液腺細胞の機能と，それを調節する 因子等についてより詳細に，系統的にそして生化 学的に検討を加えていきたい。またこの細胞を化 学物質あるいはウイルス等によりトランスホーム させることにより発癌過程における多様な変化を 追求し, 唾液腺腫瘍の病態の把握に役立てたいと 考えている。

抄録：マウス正常䪽下腺細胞（MSG 細胞）の分離及び培養を試みた。顎下腺を細切後，コラーゲナーゼ で消化し，分離された細胞をコラーゲンゲル内に包理し培羕をおこなった。MSG 細胞は樹枝状形態を示し ながら三次元的に旺盛に増殖するのみならず in vivo に類似した管腔形成を示した。一方線維芽細胞の増殖 は全く認められなかった。さらに，MSG 細胞は培養 3 週閒前後有意のアミラーゼ分泌活性を保持していた。 つまり MSG 細胞をコラーゲンゲル内で培羑することにより高い増殖能と分泌機能を保持した状態で維持す ることが可能であることが明らかとなった。今後この培羕を朋いて，種々の薬剤あるいはホルモン及び成長 因子の顎下腺細胞に対する影響を検討していきたい。 


\section{文献}

1) Barka, T. : Biologically active polypeptides in submandibular glands. J. Histochem. Cytochem. 28 : 836-859, 1980.

2) Gresik, E. W. : Postnatal developmental changes in submandibular glands of rats and mice. J. Histochem. Cytochem. $28: 860-870$, 1980.

3）田隈泰信, 市田篤郎，久米川正好：喠液腺の培 養. 歯科ジャーナル $16: 561-567,1982$.

4) Yang, J., Richards, J., Guzman, R., Imagawa, W. and Nandi, S. : Sustained growth in primary culture of normal mammary epithelial cells embedded in collagen gels. Proc. Natl. Acad. Sci. USA 77 : 2088-2092, 1980.

5) Yang, J., Flynn, D., Larson, L. and Hamamoto, S. : Growth in primary culture of mouse submandibular epithelial cells embed ded in collagen gels. In Vitro $18: 435-442$, 1982.

6) Ehmann, U. K., Peterson, W. D. and Misfeld, D. S. : To grow mouse mammary epithelial cells in culture. J. Cell Biol. 98 : 1026-1032, 1984.

7) Richards, J., Larson, L., Yang, J., Guzman, R., Tomooka, Y., Osborn, R., Imagawa, W. and Nandi, S. : Method for culturing mammary epithelial cells in a rat tail collagen gel matrix. J. Tissue Cult. Method 8:3136, 1984.

8) Caraway, W. T. : A stable starch substrate for the determination of amylase in serum and other body fluids. Am. J. Clin. Path. 32 : 67-99, 1959.

9) Selye, H., Veilleux, R. and Cantin, M. : Excessive stimulation of salivary gland growth by isoproterenol. Science 133:44-45, 1961.

10) Barka, T. : Stimulation of DNA synthesis by isoproterenol in the salivary gland. Exp. Cell Res. 39 : 355-364, 1965.

11) Hand, A. R. and Ho, B. : Mitosis and hypertrophy of intercalated duct cells and endothelial cells in the isoproterenol-treated rat parotid gland. J. Dent. Res. 64 : 1031-1038, 1985.

12) Carpenter, G. and Cohen, S. : Epidermal growth factor. Ann. Rev. Biochem. 48 : 193216, 1979.

13) Gresik, E. W., Schenkein, I., Noen, H. and Barka, T. : Hormonal regulation of epidermal growth factor and protease in the submandibular gland of the adult mouse. Endocrinology 109 : 924-929, 1981.
14) Trowell, O. A. : The culture of mature organs in a synthetic medium. Exp. Cell Res. 16 : 118-147, 1959.

15) Tapp, R. L. : An attempt to maintain cultures from the submandibular gland of the adult rat in vitro. Exp. Cell Res. 47 : 536544, 1967.

16) Lucas, D. R., Perkman, E. M. and Smith, C. : The effect of insulin, steroid and other hormones on the survival of the rat salivary glands in organ culture. Exp. Cell Res. 60 : 262-268, 1970.

17）井上秀夫, 小西洋太郎, 滰川啓子, 上野明道, 竹田義明：培羛ラット耳下腺のホルモン応答性 に関する研究. 歯基礎誌 24 : 370-378, 1982.

18) Kreider, J. : Stimulation of DNA synthesis of rat salivary gland cells in monolayer cultures by isoproterenol. Cancer Res. 30 : 980983, 1970.

19) Marcante, L. : On the in vitro behavior of mouse submaxillary gland cells. J. Cell Sci. 13 : 441-445, 1973.

20) Brown, A. M. : In vitro transformation of submandibular gland epithelial cells and fibroblasts of adult rats by methylcholanthrene. Cancer Res. 33 : 2779-2789, 1973.

21) Kanamura, S. and Barka, T. : Short term culture of dissociated rat submandibular gland cells. Lab. Invest. 32 : 366-372, 1975.

22) Wigley, C. B. and Franks, L. M. : Salivary epithelial cells in primary culture : Characterization of their growth and functional properties. J. Cell Sci. 20 : 149-165, 1976.

23) Quissell, D. O. and Redman, R. S. : Functional characteristics of dispersed rat submandibular cells. Proc. Natl. Acad. Sci. USA 76 : 2789-2793, 1979.

24) Quissell, D. O., Lafferty, J. L. and Barzen, K. A. : Dispersed rat parotid cells : Role of calcium and cAMP in the regulation of amylase secretion. J. Dent. Res. 62:131-134, 1983.

25) Quissell, D. O., Deisher, L. M. and Barzen, K. A. : The rate-determining step in cAMP. mediated exocytosis in the rat parotid and submandibular glands appear to involve analogous 26-KDa integral membrane phosphoproteins. Proc. Natl. Acad. Sci. USA 82 : 3237-3241, 1985.

26) Oliver, C. : Isolation and maintenance of differentiated exocrine gland acinar cells in vitro. In vitro 16 : 297-305, 1980.

27) Takemura, H. and Ohsika, H. : Contribution of extracellular and intracellular calcium to the enhanced effect of an $\alpha$-adrenergic agonist on amylase release from dispersed rat 
parotid cells. J. Dent. Res. 64 : 881-885, 1985.

28) Wigley, C. B. : Transformation in vitro of adult mouse salivary gland epithelium ; a system for studies on mechanisms of initiation and promotion. Neoplastic transformation in differentiated epithelial cell system in vitro. edited by Franks, L. M. and Wigley, C. B., pp. 3-34, Academic Press, London, New York, Toronto, Sydney, San Francisco, 1979.

29) Knowles, M. A. and Franks, L. M. : Stages in neoplastic transformation of adult epithelial cells by 7, 12-dimethylbenz (a) anthracene in vitro. Cancer Res. 37:3917-3924, 1977.

30) Barka, T., Noen, H., Michelakis, A. M. and Schenkein, I. : Epidermal growth factor, renin and peptidase in cultured tumor cells of submandibular gland origin. Lab. Invest. 42: 656-662, 1980.

31) Shirasuna, K., Sato, M. and Miyazaki, T. : A neoplastic epithelial duct cell line established from an irradiated human salivary gland. Cancer 48 : 745-752, 1981.
32）佐藤光信, 林 良夫, 吉田秀夫, 梁川哲雄 : 七 卜唾液腺癌細胞の增殖と分化. 臨床科学 21 : 1065-1072, 1985.

33) Levine, J. F. and Stockdale, F. E. : Cellcell interactions promote mammary epithelial cell differentiation. J. Cell Biol. 100 : 14151422, 1985.

34) Wicha, M. S., Lowrie, G., Kahn, E., Bagavandoss, P. and Mahn, T. : Extracellular matrix promotes mammary epithelial growth and differentiation in vitro. Proc. Natl. Acad. Sci. USA 79 : 3213-3217, 1982.

35) Yang, J., Larson, L. and Nandi, S. : Threedimensional growth and morphogenesis of mouse submandibular epithelial cells in serum-free primary culture. Exp. Cell Res. $137:$ 481-485, 1982.

36) Yang, J., Richards, J., Bowman, P., Guzman, R., Enami, J., McCormick, K., Hamamoto, S., Pitelka, D. and Nandi, S. : Sustained growth and three-dimensional organization of primary mammary tumor epithelial cells embedded in collagen gels. Proc. Natl. Acad. Sci. USA 76 : 3401-3405, 1979. 